\title{
Glucolipotoxicity in Pancreatic $\beta$-Cells
}

\author{
Ji-Won Kim, Kun-Ho Yoon \\ Department of Endocrinology and Metabolism, Convergent Research Consortium for Immunologic Disease, The Catholic University of Korea, Seoul, Korea
}

The recent epidemic of type 2 diabetes in Asia differs from that reported in other regions of the world in several key areas: it has evolved over a much shorter time, in an earlier stage of life, and in people with lower body mass indices. These phenotypic characteristics of patients strongly suggest that insulin secretory defects may perform a more important function in the development and progression of diabetes. A genetic element clearly underlies $\beta$-cell dysfunction and insufficient $\beta$-cell mass; however, a number of modifiable factors are also linked to $\beta$-cell deterioration, most notably chronic hyperglycemia and elevated free fatty acid (FFA) levels. Neither glucose nor FFAs alone cause clinically meaningful $\beta$-cell toxicity, especially in patients with normal or impaired glucose tolerance. Thus the term "glucolipotoxicity" is perhaps more appropriate in describing the phenomenon. Several mechanisms have been proposed to explain glucolipotoxicity-induced $\beta$-cell dysfunction and death, but its major factors appear to be depression of key transcription factor gene expression by altered intracellular energy metabolism and oxidative stress. Therefore, stabilization of metabolic changes induced by glucolipotoxicity in $\beta$-cells represents a new avenue for the treatment of type 2 diabetes mellitus.

Keywords: $\beta$-cell dysfunction; Glucolipotoxicity; Glucotoxicity; Lipotoxicity

\section{INTRODUCTION}

The number of people with type 2 diabetes has rapidly and remarkably increased throughout Asia, and the rate of increase shows no signs of slowing. This recent epidemic of type 2 diabetes in Asia differs from that reported in other regions of the world; it has evolved over a much shorter time, at an earlier stage of life, and in people with lower body mass indices [1]. Because the degree of obesity, the aging process and environmental influences on the body are closely related to insulin resistance, insulin secretory defects may perform a more important function in the development and progression of diabetes in our region [2]. Impaired insulin secretion might be induced by insufficient $\beta$-cell mass, by functional defects within the $\beta$-cells themselves, or by both of these conditions. Reductions in $\beta$-cell mass and abnormalities of $\beta$-cell function can both be demonstrated in patients with type 2 diabetes and individuals at increased risk for diabetes [3]. Whether $\beta$-cell dysfunction is caused by reduced $\beta$-cell mass or vice-versa remains to be determined. A genetic element clearly underlies $\beta$-cell dysfunction and insufficient $\beta$-cell mass; however, a number of modifiable factors are also linked to $\beta$-cell deterioration, most notably chronic hyperglycemia and elevated free fatty acid (FFA) levels [4]. Evidence has also been found for a link between increased pro-inflammatory cytokines and the impairment of insulin-signaling pathways in the $\beta$-cells, as well as the potential roles of islet amyloid deposition and fibrotic islet destruction $[5,6]$. In this review, we provide an overview of the characteristic features and underlying mechanisms of dysfunctions and death of the $\beta$-cells by glucolipotoxicity.
Corresponding author: Kun-Ho Yoon

Department of Endocrinology and Metabolism, Seoul St. Mary's Hospital, The Catholic University of Korea, 505 Banpo-dong, Seocho-gu, Seoul 137-040, Korea

E-mail:yoonk@catholic.ac.kr
This is an Open Access article distributed under the terms of the Creative Commons Attribution Non-Commercial License (http://creativecommons.org/licenses/by-nc/3.0/) which permits unrestricted non-commercial use, distribution, and reproduction in any medium, provided the original work is properly cited. 


\section{GLUCO-, LIPO- AND GLUCOLIPOTOXICITY}

\section{Glucotoxicity}

In type 2 diabetes, chronic hyperglycemia has long been felt to have negative consequences on $\beta$-cell function. The results of several studies have demonstrated that the chronic elevation of blood glucose concentration impairs $\beta$-cell function and insulin sensitivity, a phenomenon referred to as glucotoxicity $[7,8]$. Glucose has a stimulatory effect on transcription of the gene that encodes preproinsulin and also on insulin release. Glucose enters the $\beta$-cell via facilitated transport through the glucose transporter 2 (GLUT2) transporter, and then it is converted to glucose-6-phosphate (G-6-P) by the action of glucokinase (GK). The glycolytic cascade and adenosine triphosphate (ATP) production in this process ultimately leads to membrane depolarization and exocytosis of insulin granule [9]. It is understandable that repeated and prolonged exposure to hyperglycemia likely leads to $\beta$-cell degranulation and eventual exhaustion, but the mechanisms underlying this process are believed to be complex and not readily explicable. Prolonged hyperglycemia alters various $\beta$-cell-specific genes, including the transcription factors Pdx-1, BETA2/NeuroD and MafA, and other genes as well, such as insulin, PGC- $1 \alpha$, UCP, and many genes related with the glycolytic pathway [10-13]. The reduction of insulin-gene transcription is thought to be secondary to reductions in the transcription or activity of $\beta$-cell transcription factors such as Pdx1, BETA2/NeuroD and MafA [10-14]. Several mechanisms have been proposed to explain the hyperglycemia-induced loss of $\beta$-cell function, but a major factor appears to be alteration of intracellular energy metabolism and oxidative stress, as well as mitochondrial dysfunction, which will be discussed later. Other pathways linked to hyperglycemia include endoplasmic reticulum (ER) stress and possibly hypoxia-induced stress $[15,16]$. Therefore, glucose toxicity is one of the most important mechanisms of $\beta$-cell dysfunction and loss in diabetic patients. However, it is difficult to explain $\beta$-cell loss observed in the prediabetic stage [17].

\section{Lipid toxicity}

The term "lipotoxicity" is often applied to the phenomenon in which elevated FFA levels in the setting of insulin resistance contribute to $\beta$-cell dysfunction. In actuality, the effect of FFA on $\beta$-cell function is much more complex, and it includes both beneficial and detrimental effects [18]. Duration of exposure to elevated FFA and the coexistence of hyperglycemia influ- ence the extent to which FFA levels contribute to $\beta$-cell function. Some FFAs and lipoproteins may exert a pro-apoptotic effect, whereas others appear to perform a protective function. Therefore, long-term exposure to saturated fatty acids (such as palmitate) is associated with toxic effects, whereas monounsaturated fatty acids (such as oleate) protect against palmitateand glucose-induced $\beta$-cell apoptosis [19]. Exposure to FFA in the long-term leads to impaired insulin gene transcription, impaired glucose-stimulated insulin secretion (GSIS) and eventual $\beta$-cell apoptosis [20]. Researchers have studied the mechanisms by which healthy concentrations of FFA promote GSIS, and at least two distinct pathways have emerged. The first is through the free fatty acid receptor (Gpr40) [21]. Alquier et al. [22] recently showed that the knockout of GPR40 led to impairments in glucose- and FFA-stimulated insulin secretion in islets without affecting intra-islet glucose or palmitate metabolism. The second pathway is through intracellular FFA metabolism and glycerolipid/FFA cycling [23]. In the aggregate, these mechanisms are believed to maintain GSIS under normal circumstances and possibly contribute to the early hypersecretion of insulin in the initial stages of high-fat diet-induced obesity [24]. Emerging data additionally implicate a possible role for cholesterol metabolism in $\beta$-cell lipotoxicity. Oxidized low density lipoprotein particles appear to diminish insulin gene transcription and promote apoptosis in isolated $\beta$-cells [25]. Disruption of the ABCA1 reverse cholesterol transporter in mice results in defects in cholesterol efflux from the $\beta$-cell and subsequent accumulation of intra-islet cholesterol; this accumulation leads to impaired GSIS and glucose intolerance [26]. In this regard, recent studies by our group suggest that activation of ABCA1 in human islets by LXR agonists might be one approach to diminish islet cholesterol burden and to improve GSIS [27].

\section{Glucolipotoxicity}

This finding is consistent with the glucolipotoxicity hypothesis, which states that neither glucose nor FFAs alone cause clinically meaningful $\beta$-cell toxicity [3]. The term "glucolipotoxicity" is perhaps more appropriate in describing the phenomenon. The effect of glucose on FFA toxicity in the $\beta$-cell has been suggested to be secondary to a partitioning effect on lipid metabolism [28]. Several mechanisms have been proposed to explain the chronic effects of FFA on GSIS and $\beta$-cell apoptosis. Prolonged exposure to palmitic acid diminishes insulin gene transcription and GSIS in isolated rat islets, and it is 


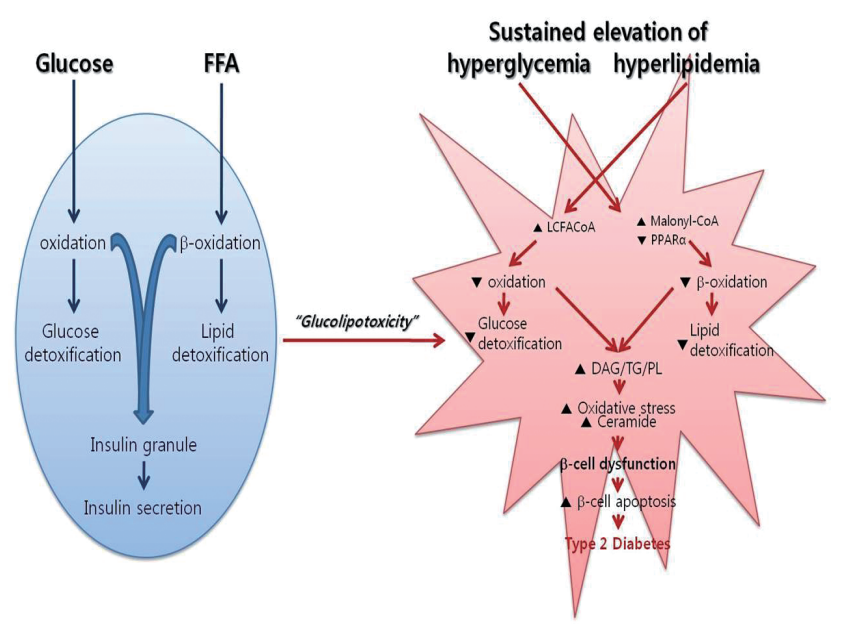

Fig. 1. Mechanism of pancreatic $\beta$-cell glucolipotoxicity. Normal laboratory ranges of glucose and fatty acids are not toxic to $\beta$-cells. The problems arise when $\beta$-cells experience prolonged exposure of sustained elevation of hyperglycemia together with elevated hyperlipidemia. Chronic high glucose levels exert a significant effect on $\beta$-cell lipid metabolism via altered enzyme activity and expression of key transcription factors. The consequent change in cellular energy metabolism results in glucolipotoxicity, which induces $\beta$-cell apoptotic cell death and promotes type 2 diabetes. FFA, free fatty acid; LCFACoA, long-chain fatty acyl-CoA; DAG, diacylglycerol; TG, triglyceride; PL, phospholipid.

accompanied by attenuated binding of the $\beta$-cell-specific transcription factors Pdx1 and MafA [29]. Other mechanisms of glucolipotoxicity include palmitic acid-induced synthesis of ceramides, which inhibits the anti-apoptotic protein Bcl-2 and downregulates IRS-1/2 signaling [19,30]; FFA-induced up regulation of UCP2 and reduction of glucose-stimulated ATP generation [31,32]; and activation of the oxidative stress [33] and the unfolded protein response [34] pathways. Elevated glucose concentration alone is not toxic to islet tissue in normal or prediabetic stages. The $\beta$-cell adapts via changes in gene expression, such as glycolytic and anaplerotic genes induction $[35,36]$. These results induce GSIS and glucose detoxification in the pancreatic $\beta$-cell [37]. Elevated fatty acids alone also are nontoxic because FFAs will be oxidized in the $\beta$-cell at low glucose and in the absence of increased malonyl-CoA levels, resulting in lipid detoxification [38]. However, prolonged exposure to high glucose and FFAs would subsequently result from the progressive accumulation of FFA-derived long-chain acylCoA esters (FACoAs) and various lipid-signaling molecules in the $\beta$-cell. These factors may cause impaired glucose-induced insulin secretion and biosynthesis and promote apoptotic cell

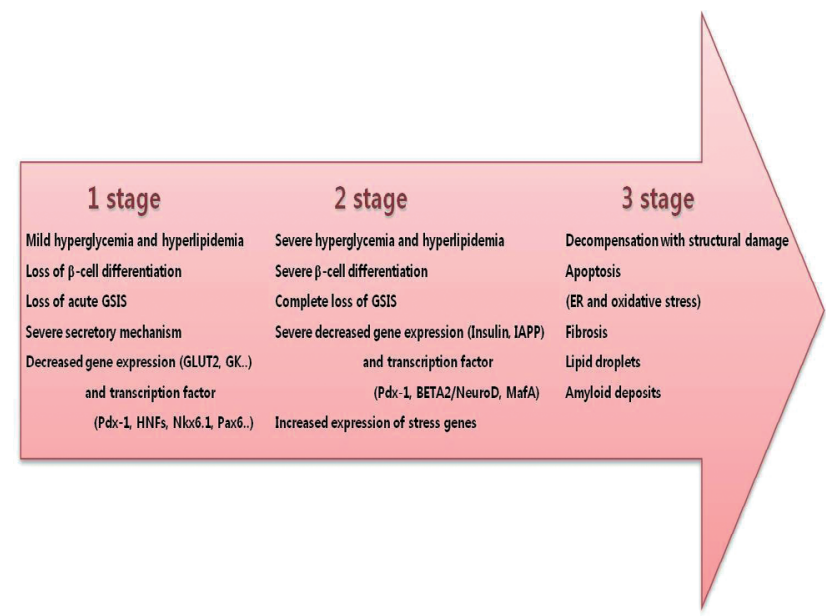

Fig. 2. Progression from the normal state to severe diabetes. This panel shows the changes that occur in $\beta$-cells during the three-stage progression from the normal state to severe diabetes. GSIS, glucose-stimulated insulin secretion; GLUT2, glucose transporter2; GK, glucokinase; IAPP, islet amyloid polypeptide; ER, endoplasmic reticulum.

death (Fig. 1). Recently, our laboratory also demonstrated the depression of important pancreas key transcription factors by glucolipotoxicity. Kim et al. [13] reported that PGC-1 $\alpha$ inhibits insulin and BETA2/NeuroD transcription levels and that attenuating PGC-1 $\alpha$ overexpression protects against glucolipotoxicity-induced $\beta$-cell dysfunction. Although the basal PGC-1 $\alpha$ expression level was very low in fresh, isolated rat islets in our study, it increased gradually with time under glucolipotoxic conditions. After three days of exposure to such high glucose concentrations, insulin and BETA2/NeuroD gene expression levels were downregulated significantly. An even more interesting finding was that the suppression of the Pdx-1 gene needed more time after exposure to glucolipotoxic conditions, and then it gradually decreased. We suggest that PGC- $1 \alpha$ played important key roles in intracellular fuel regulation and could herald in a new era in the treatment of patients with type 2 diabetes mellitus by providing protection from glucolipotoxicity, which is an important cause of the development and progression of the disease (Fig. 2).

\section{STAGES OF GLUCOLIPOTOXICITY}

We viewed the changes that occurred in $\beta$-cells during the progression from the normal state to severe diabetes as consisting of three stages (Fig. 3). We cited much of stages of glucolipotoxicity in a similar manner as those referenced in Weir 


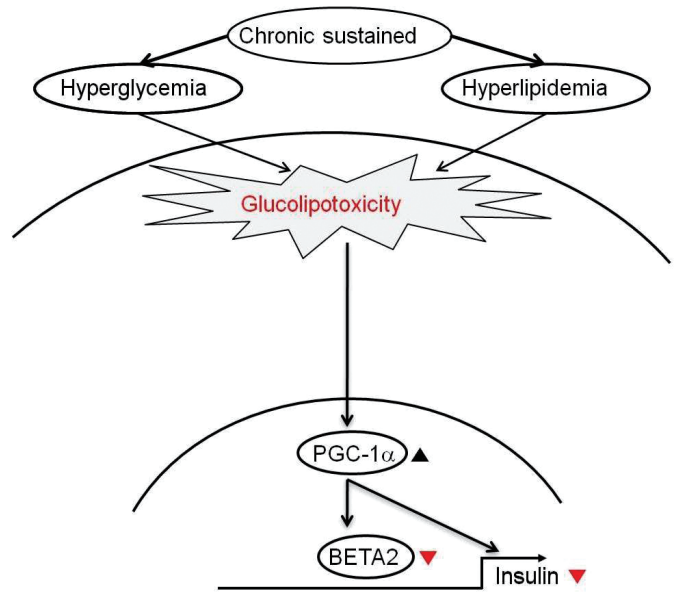

Fig. 3. Working hypothesis in glucolipotoxicity-induced $\beta$-cell dysfunction. PGC-1 $\alpha$ inhibits insulin and BETA2/NeuroD transcription levels, and attenuating PGC-1 $\alpha$ overexpression protects against glucolipotoxicity-induced $\beta$-cell dysfunction [13].

et al. [39].

\section{Stage 1: mild decompensation}

In this stage, there is a specific loss of GSIS, whereas insulin secretion to other secretagogues, such as arginin, IBMX and GLP-1, is preserved. Insulin stores in the $\beta$-cells are well preserved, suggesting that secretory mechanisms (including channel activities, membrane docking of insulin granules and mitochondrial ATP production) are more severely affected than those of insulin synthesis [40]. A loss of $\beta$-cell differentiation can be found at this stage, but insulin mRNA levels are protected, which probably allows insulin production to be reasonably well maintained for the degree of $\beta$-cell deficiency.

\section{Stage 2: severe decompensation}

$\beta$-cells are degranulated, which coincides with a decrease in insulin mRNA, pointing to decreased insulin synthesis. In this situation, $\beta$-cell differentiation is grossly deranged, with alterations of metabolic genes and key transcription factors ( $\mathrm{Pdx}-1$, BETA2/NeuroD, and MafA), as well as increased expression of several important stress genes (A20 and Heme oxygenase-1).

\section{Stage 3: decompensation with structural damage and death of $\beta$-cells}

Islets can transition from having a relatively normal structure with abnormal function to a stage of obvious structural damage. Amyloid formation in human type 2 diabetes is a striking

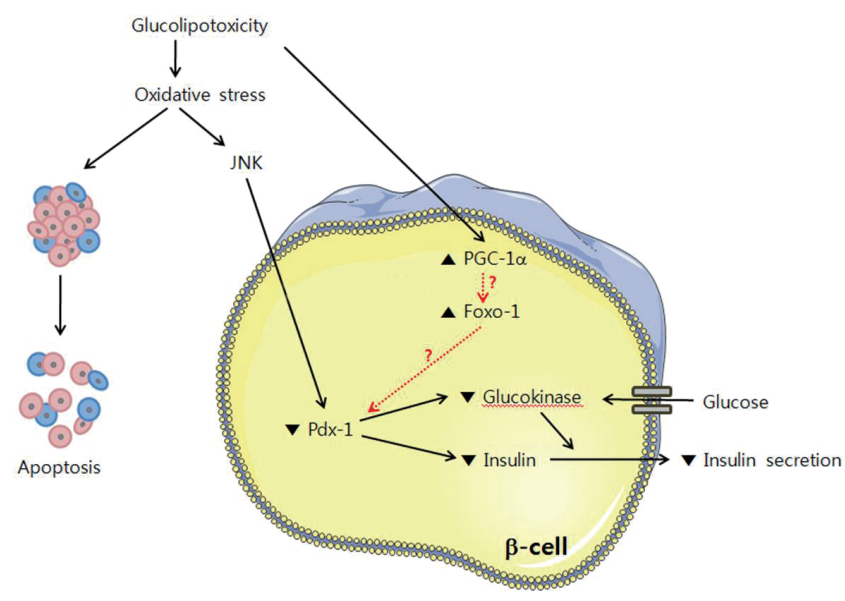

Fig. 4. $\beta$-cell dysfunction by glucolipotoxicity. Under glucolipotoxic conditions, oxidative stress is induced and the JNK pathway is activated. PDX-1 is translocated pathogenically from the nucleus to the cytoplasm by JNK activation and finally induces suppression of insulin secretion [41].

abnormality. Amyloid fibrils can have a destructive effect on $\beta$-cells, but we know little about the mechanisms responsible for their formation. Lipid droplets are sometimes found in $\beta$-cells, which raises questions about lipotoxicity. Islet fibrosis can also be found. Although it is tempting to suggest that an increased rate of apoptosis must be important for the development of human type 2 diabetes, it is possible that limitations of islet neogenesis and $\beta$-cell replication are at least as important. Severe $\beta$-cell ER stress leading to strong activation of the UPR might cause apoptosis, which is mediated by stress kinases and transcription factors, such as Jun N-terminal kinase (JNK) and $\mathrm{C} / \mathrm{Ebp}$-homologous protein (CHOP). Importantly, disruption of the CHOP gene was shown to inhibit $\beta$-cell apoptosis, expand $\beta$-cell mass and improve glycemic control in mouse models of diabetes, which suggests that the UPR plays an important role in mediating the $\beta$-cell dysfunction of diabetes. We found that glucose moderately stimulates ER stress; however, high glucose levels synergize with fatty acids to stimulate UPR and JNK with $\beta$-cell apoptosis as a consequence. Chronic exposure to high glucose is expected to increase the metabolic flux in mitochondria and lead to excess production of reactive oxygen species (ROS) through the hexosamine pathway. The level of oxidative stress exerted on the $\beta$-cell depends on its capacity to scavenge ROS and other free radicals generated under conditions of glucolipotoxicity. Oxidative stress and/or activation of the JNK pathway suppresses insulin gene expression, which is accompanied by reduction of PDX-1 [41]. Interesting- 
ly, elevation of PGC- $1 \alpha$ by glucolipotoxicity might promote or enhance the harmful effects of the JNK pathway (Fig. 4).

\section{SUMMARY AND CONCLUSION}

Progressive loss of $\beta$-cell function and mass with aging are observed in type 2 diabetic patients and even in people with normal glucose tolerance. A genetic element clearly underlies $\beta$-cell dysfunction and insufficient $\beta$-cell mass; however, a number of modifiable factors are also linked to $\beta$-cell deterioration, most notably chronic hyperglycemia and elevated FFA levels. Pancreatic $\beta$-cells exposed to high glucose and lipid concentrations display altered gene expression, function, survival, and growth that may contribute to the slow deterioration of the functional $\beta$-cell mass in type 2 diabetes. These glucolipotoxic alterations may result from various types of stress, including oxidative stress, ER stress, cytokine-induced apoptosis, and hypoxia. A clearer understanding about the differences of energy metabolism between normal and pathologic conditions and related alterations of important genes expression in $\beta$-cells should help explain the mechanism of glucolipotoxicity in $\beta$-cells.

\section{CONFLICTS OF INTEREST}

No potential conflict of interest relevant to this article was reported.

\section{ACKNOWLEDGMENTS}

This research was supported by Basic Science Research Program through the National Research Foundation of Korea (NRF) funded by the Ministry of Education, Science and Technology (20110009075).

\section{REFERENCES}

1. Yoon KH, Lee JH, Kim JW, Cho JH, Choi YH, Ko SH, Zimmet P, Son HY. Epidemic obesity and type 2 diabetes in Asia. Lancet 2006;368:1681-8.

2. Kahn SE. The relative contributions of insulin resistance and beta-cell dysfunction to the pathophysiology of type 2 diabetes. Diabetologia 2003;46:3-19.

3. Prentki M, Nolan CJ. Islet beta cell failure in type 2 diabetes. J Clin Invest 2006;116:1802-12.
4. Cho JH, Kim JW, Shin JA, Shin J, Yoon KH. Beta-cell mass in people with type 2 diabetes. J Diabetes Invest 2011;2:6-17.

5. Maedler K, Sergeev P, Ris F, Oberholzer J, Joller-Jemelka HI, Spinas GA, Kaiser N, Halban PA, Donath MY. Glucose-induced beta cell production of IL-1beta contributes to glucotoxicity in human pancreatic islets. J Clin Invest 2002;110:851-60.

6. Kim JW, Ko SH, Cho JH, Sun C, Hong OK, Lee SH, Kim JH, Lee KW, Kwon HS, Lee JM, Song KH, Son HY, Yoon KH. Loss of beta-cells with fibrotic islet destruction in type 2 diabetes mellitus. Front Biosci 2008;13:6022-33.

7. Kaiser N, Leibowitz G, Nesher R. Glucotoxicity and beta-cell failure in type 2 diabetes mellitus. J Pediatr Endocrinol Metab 2003;16:5-22.

8. Jonas JC, Bensellam M, Duprez J, Elouil H, Guiot Y, Pascal SM. Glucose regulation of islet stress responses and beta-cell failure in type 2 diabetes. Diabetes Obes Metab 2009;11 Suppl 4:65-81.

9. Henquin JC. Pathways in beta-cell stimulus-secretion coupling as targets for therapeutic insulin secretagogues. Diabetes 2004; 53 Suppl 3:S48-58.

10. Olson LK, Redmon JB, Towle HC, Robertson RP. Chronic exposure of HIT cells to high glucose concentrations paradoxically decreases insulin gene transcription and alters binding of insulin gene regulatory protein. J Clin Invest 1993;92:514-9.

11. Poitout V, Olson LK, Robertson RP. Chronic exposure of betaTC- 6 cells to supraphysiologic concentrations of glucose decreases binding of the RIPE3b1 insulin gene transcription activator. J Clin Invest 1996;97:1041-6.

12. Sharma A, Olson LK, Robertson RP, Stein R. The reduction of insulin gene transcription in HIT-T15 beta cells chronically exposed to high glucose concentration is associated with the loss of RIPE3b1 and STF-1 transcription factor expression. Mol Endocrinol 1995;9:1127-34.

13. Kim JW, You YH, Ham DS, Cho JH, Ko SH, Song KH, Son HY, Suh-Kim H, Lee IK, Yoon KH. Suppression of peroxisome proliferator-activated receptor gamma-coactivator-1alpha normalizes the glucolipotoxicity-induced decreased BETA2/NeuroD gene transcription and improved glucose tolerance in diabetic rats. Endocrinology 2009;150:4074-83.

14. Weir GC, Bonner-Weir S. Five stages of evolving beta-cell dysfunction during progression to diabetes. Diabetes 2004;53 Suppl 3:S16-21.

15. Kajimoto Y, Kaneto H. Role of oxidative stress in pancreatic beta-cell dysfunction. Ann N Y Acad Sci 2004;1011:168-76.

16. Robertson RP. Chronic oxidative stress as a central mechanism for glucose toxicity in pancreatic islet beta cells in diabetes. J 
Biol Chem 2004;279:42351-4.

17. Ritzel RA, Butler AE, Rizza RA, Veldhuis JD, Butler PC. Relationship between beta-cell mass and fasting blood glucose concentration in humans. Diabetes Care 2006;29:717-8.

18. Poitout V, Amyot J, Semache M, Zarrouki B, Hagman D, Fontes G. Glucolipotoxicity of the pancreatic beta cell. Biochim Biophys Acta 2010;1801:289-98.

19. Maedler K, Oberholzer J, Bucher P, Spinas GA, Donath MY. Monounsaturated fatty acids prevent the deleterious effects of palmitate and high glucose on human pancreatic beta-cell turnover and function. Diabetes 2003;52:726-33.

20. Zhou YP, Grill VE. Long-term exposure of rat pancreatic islets to fatty acids inhibits glucose-induced insulin secretion and biosynthesis through a glucose fatty acid cycle. J Clin Invest 1994;93:870-6.

21. Tan CP, Feng Y, Zhou YP, Eiermann GJ, Petrov A, Zhou C, Lin S, Salituro G, Meinke P, Mosley R, Akiyama TE, Einstein M, Kumar S, Berger JP, Mills SG, Thornberry NA, Yang L, Howard AD. Selective small-molecule agonists of G protein-coupled receptor 40 promote glucose-dependent insulin secretion and reduce blood glucose in mice. Diabetes 2008;57:2211-9.

22. Alquier T, Peyot ML, Latour MG, Kebede M, Sorensen CM, Gesta S, Ronald Kahn C, Smith RD, Jetton TL, Metz TO, Prentki M, Poitout V. Deletion of GPR40 impairs glucose-induced insulin secretion in vivo in mice without affecting intracellular fuel metabolism in islets. Diabetes 2009;58:2607-15.

23. Nolan CJ, Prentki M. The islet beta-cell: fuel responsive and vulnerable. Trends Endocrinol Metab 2008;19:285-91.

24. Boden G, Chen X, Rosner J, Barton M. Effects of a 48-h fat infusion on insulin secretion and glucose utilization. Diabetes 1995;44:1239-42.

25. Cnop M, Hannaert JC, Grupping AY, Pipeleers DG. Low density lipoprotein can cause death of islet beta-cells by its cellular uptake and oxidative modification. Endocrinology 2002;143: 3449-53.

26. Brunham LR, Kruit JK, Pape TD, Timmins JM, Reuwer AQ, Vasanji Z, Marsh BJ, Rodrigues B, Johnson JD, Parks JS, Verchere CB, Hayden MR. Beta-cell ABCA1 influences insulin secretion, glucose homeostasis and response to thiazolidinedione treatment. Nat Med 2007;13:340-7.

27. Ogihara T, Chuang JC, Vestermark GL, Garmey JC, Ketchum RJ, Huang X, Brayman KL, Thorner MO, Repa JJ, Mirmira RG, Evans-Molina C. Liver X receptor agonists augment human islet function through activation of anaplerotic pathways and glycerolipid/free fatty acid cycling. J Biol Chem 2010;285:
5392-404.

28. Prentki M, Vischer S, Glennon MC, Regazzi R, Deeney JT, Corkey BE. Malonyl-CoA and long chain acyl-CoA esters as metabolic coupling factors in nutrient-induced insulin secretion. J Biol Chem 1992;267:5802-10.

29. Hagman DK, Hays LB, Parazzoli SD, Poitout V. Palmitate inhibits insulin gene expression by altering PDX-1 nuclear localization and reducing MafA expression in isolated rat islets of Langerhans. J Biol Chem 2005;280:32413-8.

30. Solinas G, Naugler W, Galimi F, Lee MS, Karin M. Saturated fatty acids inhibit induction of insulin gene transcription by JNK-mediated phosphorylation of insulin-receptor substrates. Proc Natl Acad Sci U S A 2006;103:16454-9.

31. Joseph JW, Koshkin V, Zhang CY, Wang J, Lowell BB, Chan $\mathrm{CB}$, Wheeler MB. Uncoupling protein 2 knockout mice have enhanced insulin secretory capacity after a high-fat diet. Diabetes 2002;51:3211-9.

32. Joseph JW, Koshkin V, Saleh MC, Sivitz WI, Zhang CY, Lowell BB, Chan CB, Wheeler MB. Free fatty acid-induced beta-cell defects are dependent on uncoupling protein 2 expression. J Biol Chem 2004;279:51049-56.

33. Piro S, Anello M, Di Pietro C, Lizzio MN, Patane G, Rabuazzo AM, Vigneri R, Purrello M, Purrello F. Chronic exposure to free fatty acids or high glucose induces apoptosis in rat pancreatic islets: possible role of oxidative stress. Metabolism 2002;51: 1340-7.

34. Laybutt DR, Preston AM, Akerfeldt MC, Kench JG, Busch AK, Biankin AV, Biden TJ. Endoplasmic reticulum stress contributes to beta cell apoptosis in type 2 diabetes. Diabetologia 2007; 50:752-63.

35. Roche E, Assimacopoulos-Jeannet F, Witters LA, Perruchoud B, Yaney G, Corkey B, Asfari M, Prentki M. Induction by glucose of genes coding for glycolytic enzymes in a pancreatic beta-cell line (INS-1). J Biol Chem 1997;272:3091-8.

36. Roche E, Farfari S, Witters LA, Assimacopoulos-Jeannet F, Thumelin S, Brun T, Corkey BE, Saha AK, Prentki M. Longterm exposure of beta-INS cells to high glucose concentrations increases anaplerosis, lipogenesis, and lipogenic gene expression. Diabetes 1998;47:1086-94.

37. Farfari S, Schulz V, Corkey B, Prentki M. Glucose-regulated anaplerosis and cataplerosis in pancreatic beta-cells: possible implication of a pyruvate/citrate shuttle in insulin secretion. Diabetes 2000;49:718-26.

38. Prentki M, Joly E, El-Assaad W, Roduit R. Malonyl-CoA signaling, lipid partitioning, and glucolipotoxicity: role in beta- 
cell adaptation and failure in the etiology of diabetes. Diabetes 2002;51 Suppl 3:S405-13.

39. Weir GC, Laybutt DR, Kaneto H, Bonner-Weir S, Sharma A. Beta-cell adaptation and decompensation during the progression of diabetes. Diabetes 2001;50 Suppl 1:S154-9.

40. Grill V, Bjorklund A. Dysfunctional insulin secretion in type 2 diabetes: role of metabolic abnormalities. Cell Mol Life Sci 2000;57:429-40.

41. Kaneto H, Matsuoka TA, Nakatani Y, Kawamori D, Miyatsuka T, Matsuhisa M, Yamasaki Y. Oxidative stress, ER stress, and the JNK pathway in type 2 diabetes. J Mol Med (Berl) 2005;83: 429-39. 